\title{
Pemilihan Jenis Sistem Pengelolaan Air Limbah Domestik di Kecamatan Bekasi Selatan
}

\author{
Qurrotul Uyun, Eka Wardhani, dan Nico Halomoan \\ Jurusan Teknik Lingkungan, Fakultas Teknik Sipil dan Perencanaan, ITENAS, Bandung, \\ Email : qurrotuluyun12@gmail.com
}

\begin{abstract}
ABSTRAK
Kawasan prioritas pada Kecamatan Bekasi Selatan adalah kawasan permukiman sepanjang Kali Bekasi. Kurangnya sarana dan prasana dalam penyaluran air limbah domestik telah memberikan kontribusi pencemaran cukup tinggi kepada penurunan kualitas air Kali Bekasi. Dampak dari aktivitas sehari-hari masyarakat yang menjadi kebiasaan seperti buang air besar sembarang di sembarang tempat, tidak memiliki tangki septik sebagai tempat buang air besar, dan air bekas mandi dan cucian yang dibuang ke saluran drainase maupun secara langsung ke badan air juga menyebabkan buruknya tingkat sanitasi di Kecamatan Bekasi Selatan. Kondisi sanitasi Kecamatan Bekasi Selatan teridentifikasi beresiko tinggi berdasarkan Environmental Health Risk Assesment. Oleh Karena itu perlu dilakukan pembangunan Sistem Pengelolaan Air Limbah Domestik berdasarkan Peraturan Menteri Pekerjaan Umum dan Perumahan Rakyat Republik Indonesia Nomor 4 Tahun 2017 tentang Penyelenggaraan Sistem Pengelolaan Air Limbah Domestik pada Lampiran I. SPALD yang terpilih pada Kecamatan Bekasi Selatan yaitu Sistem Pengelolaan Air Limbah Domestik Setempat skala Komunal.
\end{abstract}

Kata kunci: Kecamatan Bekasi Selatan, Tingkat Sanitasi, SPALD.

\begin{abstract}
Priority area in South Bekasi District is a residential area along Bekasi River. The lack of facilities and infrastructures in the distribution of domestic wastewater has contributed to pollution which is high enough to decrease the quality of Bekasi River water. The impact of the daily activities of the community which becomes a habit such as defecating in any place, does not have a septic tank as a place to defecate, and used bathing water and laundry which are discharged into the drainage channel or directly to the body of water also causes poor levels sanitation in South Bekasi District. Sanitation conditions in South Bekasi District were identified as high risk based on Environmental Health Risk Assessment. Therefore it is necessary to develop a Domestic Wastewater Management System based on the Republic of Indonesia Minister of Public Works and Housing Regulation No. 4 concerning the Implementation of Domestic Wastewater Management Systems in Appendix I. Selected SPALD in South Bekasi District, namely Local Domestic Wastewater Management System Communal scale.
\end{abstract}

Keywords: Sub-district, sanitation level, SPALD. 


\section{PENDAHULUAN}

Kota Bekasi merupakan kota metropolitan dengan jumlah penduduk 2.873.484 jiwa pada tahun 2017 yang tersebar di 12 Kecamatan. Salah satu kecamatan di wilayah ini yaitu Kecamatan Bekasi Selatan yang memiliki 5 Kelurahan, yaitu Jaka Mulya, Jaka Setya, Pekayon Jaya, Marga Jaya, dan Kayuringin Jaya. Kecamatan Bekasi Selatan merupakan pusat aktivitas pemerintahan dengan luas wilayah 1.606 Ha dihuni oleh 229.809 jiwa penduduk dengan kepadatan sekitar $154 \mathrm{Jiwa} / \mathrm{Ha}$. Letak geografis Kecamatan Bekasi Selatan serta fungsi sebagai pusat pemerintahan menyebabkan pertumbuhan penduduk meningkat setiap tahun. Meningkatnya pertumbuhan penduduk menyebabkan kebutuhan air bersih sebagai penunjang kebutuhan sehari-hari meningkat. Akibatnya, timbulan air limbah domestik pun menjadi meningkat. Dampak ikutannya berupa peningkatan risiko sanitasi [1].

Berdasarkan Status Lingkungan Hidup (SLH) Kota Bekasi di Kecamatan Bekasi Selatan 7,75\% penduduk memiliki Jamban Sehat Permanen (JSP), 0,01\% penduduk memiliki Jamban Sehat Semi Permanen (JSSP), 1,16\% penduduk menggunakan fasilitas bersama, dan 91,08\% penduduk masih melakukan Buang Air Besar Sembarangan (BABs) ke sungai atau saluran drainase. Kebiasaan BABs tempat, tidak memiliki tangki septik sebagai tempat buang air besar, dan air bekas mandi dan cucian yang dibuang ke saluran drainase maupun secara langsung ke badan air menyebabkan terjadinya pencemaran air sungai. Badan Pengelolaan Lingkungan Hidup Daerah (BPLHD) Kota Bekasi tahun 2017 menyatakan bahwa Kali Bekasi telah tercemar oleh Chemical Oxygen Demand (COD) dan Biological Oxygen Demand $\left(\mathrm{BOD}_{5}\right)$. Konsentrasi $\mathrm{BOD}_{5}$ dan $\mathrm{COD}$ di Kali Bekasi terpantau sebesar $148,47 \mathrm{mg} / \mathrm{L}$ dan 525,68 mg/L tidak memenuhi bakumutu berdasarkan Peraturan Pemerintah (PP) Nomor 82 Tahun 2001 (PP No82/2001) tentang Pengelolaan Kualitas Air dan Pengendalian Pencemaran Air. Peraturan pemerintah tersebut mengatur konsentrasi BOD5 dan COD masing-masing sebesar $12 \mathrm{mg} / \mathrm{L}$ dan $100 \mathrm{mg} / \mathrm{L}$ peruntukan air kelas II.

Berdasarkan permasalahan di atas maka perlu dilakukan pembangunan Sistem Pengelolaan Air Limbah Domestik (SPALD). Langkah awal pembangunan SPALD yaitu melakukan pemilihan sistem yang paling sesuai untuk wilayah Kecamatan Bekasi Selatan. Berdasarkan uraian di atas maka tujuan dari penelitian ini yaitu melakukan penapisan untuk menentukan SPALD yang paling tepat diterapkan di kecamatan tersebut. Pembangunan SPALD yang sesuai wilayah kajian diharapkan menjadi solusi masalah sanitasi, sehingga pencegahan pencemaran lingkungan dan meningkatnya taraf kesehatan masyarakat. Pertimbangan pemilihan jenis SPALD mengacu kepada Lampiran I Peraturan Menteri Pekerjaan Umum dan Perumahan Rakyat Republik Indonesia Nomor 4 Tahun 2017 (Permen PUPR No 4/2017) tentang Penyelenggaraan SPALD. Pertimbangan tersebut ditentukan berdasarkan penilaian 5 parameter yang telah ditetapkan yaitu kepadatan penduduk, kedalaman muka air tanah, permeabilitas tanah, kemampuan pembiayaan, dan kemiringan tanah.

\section{TINJAUAN TEORITIS}

Menurut Permen PUPR No. 4/2017 air limbah domestik merupakan air limbah yang berasal dari usaha dan/atau kegiatan pemukiman, rumah makan, perkantoran, perniagaan, apartemen, dan asrama. Berdasarkan pernyataan tersebut dapat disederhanakan bahwa air yang berasal dari sisa kebersihan aktivitas sehari-hari pada pemukiman yaitu limbah dapur, kamar mandi, toilet, cucian, dan sebagainnya termasuk air limbah domestik. Menurut Mubin [2] terdapat tiga fraksi penting pada komposisi air limbah domestik, yaitu tinja (feces) yang berpotensi memiliki kandungan mikroba pathogen, air seni (urine) 
yang berpotensi memiliki kandungan Nitrogen $(\mathrm{N})$ dan Posfor $(\mathrm{P})$ secara umum dan mikroorganisme pada kemungkinan kecil, dan air kotor (Grey Water) yang merupakan air bekas cucian dapur, mesin cuci dan kamar mandi.

Air limbah domestik perlu penanganan untuk menghindari permasalahan pencemaran lingkungan khususnya air dan tanah. Permen PUPR No.4/2017 mendefinisikan SPALD sebagai rangkaian kegiatan pengelolaan air limbah domestik dalam satu kesatuan dengan prasarana dan sarana pengelolaan air limbah domestik. Penanganan pada penyaluran air limbah domestik ada dua jenis, yaitu sistem terpusat (off site) dan setempat (on site).

SPALD setempat selanjutnya disebut SPALD-S merupakan pengelolaan air limbah dengan cara tidak dikumpulkan serta disalurkan ke dalam suatu jaringan saluran yang akan membawanya ke suatu tempat pengolahan air buangan atau badan air penerima, melainkan dibuang di tempat. Contohnya adalah jamban cubluk dan tangki septik. Sistem ini dipakai jika syarat-syarat teknis lokasi dapat dipenuhi dan menggunakan biaya relatif rendah [3]. Jenis SPALD-S antara lain:

- Cubluk (pit privy), merupakan sistem pembuangan tinja yang paling sederhana. Terdiri atas lubang yang digali secara manual dengan dilengkapi dinding rembes air yang dibuat dari pasangan batu bata berongga, anyaman bambu dan lain lain

- Tangki septik merupakan suatu ruangan yang terdiri atas beberapa kompartemen yang berfungsi sebagai bangunan pengendap untuk menampung kotoran padat agar mengalami pengolahan biologis oleh bakteri anaerob dalam jangka waktu tertentu. Cara untuk mendapat proses yang baik, sebuah tangki septik harus terisi hampir penuh dengan cairan, oleh karena itu tangki septik haruslah kedap air

- Beerput, sistem ini merupakan gabungan antara bak septik dan peresapan sehingga bentuknya hampir seperti sumur resapan

Komponen SPALD-S terdiri dari sistem pengolahan setempat, sistem pengolahan setempat yang berfungsi untuk mengumpulkan dan mengolah air limbah domestik (black water dan grey water) di lokasi sumber. Kapasitas pengolahan terdiri atas skala individual dapat berupa cubluk kembar, tangki septik dengan bidang resapan, biofilter dan unit pengolahan air limbah fabrikasi dan skala komunal diperuntukkan bagi dua sampai dengan sepuluh unit rumah tinggal dan Mandi Cuci Kakus (MCK), dapat berupa permanen dan non permanen (mobile toilet).

SPALD terpusat atau SPALD-T merupakan sistem yang menyalurkan air limbah domestik keluar dari lokasi pekarangan masing-masing rumah ke saluran pengumpul air buangan dan selanjutnya disalurkan secara terpusat ke bangunan pengolahan air buangan sebelum dibuang ke badan perairan. Contoh dari sistem ini antara lain mandi cuci kakus (MCK) dan jaringan air perpipaan atau limbah (public sewer) [3]. Komponen SPALD-T terdiri dari: sistem pelayanan merupakan prasarana dan sarana untuk menyalurkan air limbah domestik dari sumber melalui perpipaan sistem pengumpulan. Sistem Pelayanan meliputi pipa tinja, pipa non tinja, bak perangkap lemak dan minyak dari dapur, pipa persil, dan bak kontrol. Sistem pengumpulan merupakan prasarana dan sarana untuk menyalurkan air limbah domestik melalui perpipaan dari sistem pelayanan ke sistem pengolahan terpusat. Sistem pengumpulan terdiri dari pipa retikulasi, pipa induk, dan prasarana dan sarana pelengkap. Sistem pengolahan terpusat merupakan prasarana dan sarana untuk mengolah air limbah domestik yang dialirkan dari sumber melalui sistem pelayanan dan system pengumpulan [4]. 
Pemilihan jenis SPALD dilaksanakan dengan mempertimbangkan:

(1) kepadatan penduduk, tingkat kepadatan penduduk yang biasa digunakan dalam perencanaan SPALD yaitu 150 jiwa/Ha;

(2) kedalaman muka air tanah digunakan sebagai kriteria dalam penetapan SPALD. Untuk muka air tanah lebih kecil dari 2 meter atau jika air tanah sudah tercemar, digunakan SPALD-T;

(3) kemiringan tanah, penerapan jaringan pengumpulan air limbah domestik sesuai jika kemiringan tanah sama dengan atau lebih dari $2 \%$ (dua persen), sedangkan shallow sewer dan small bore sewer dapat digunakan pada berbagai kemiringan tanah;

(4) permeabilitas tanah sangat mempengaruhi penentuan jenis SPALD, khususnya untuk penerapan sistem pengolahan setempat (cubluk maupun tangki septik dengan bidang resapan). Langkah untuk mengetahui besar kecilnya permeabilitas tanah dapat diperkirakan dengan memperhatikan jenis tanah dan angka infiltrasi tanah atau berdasarkan tes perkolasi tanah. Permeabilitas yang efektif yaitu $5 \times 10^{-4} \mathrm{~m} /$ detik dengan jenis tanah pasir halus sampai dengan pasir yang mengandung lempung; dan

(5) kemampuan pembiayaan dapat mempengaruhi pemilihan jenis SPALD, terutama kemampuan Pemerintah Daerah dalam membiayai pengoperasian dan pemeliharaan SPALD-T [5]. Pemilihan jenis SPALD dapat mengacu pada diagram alir yang disajikan pada Gambar 1.

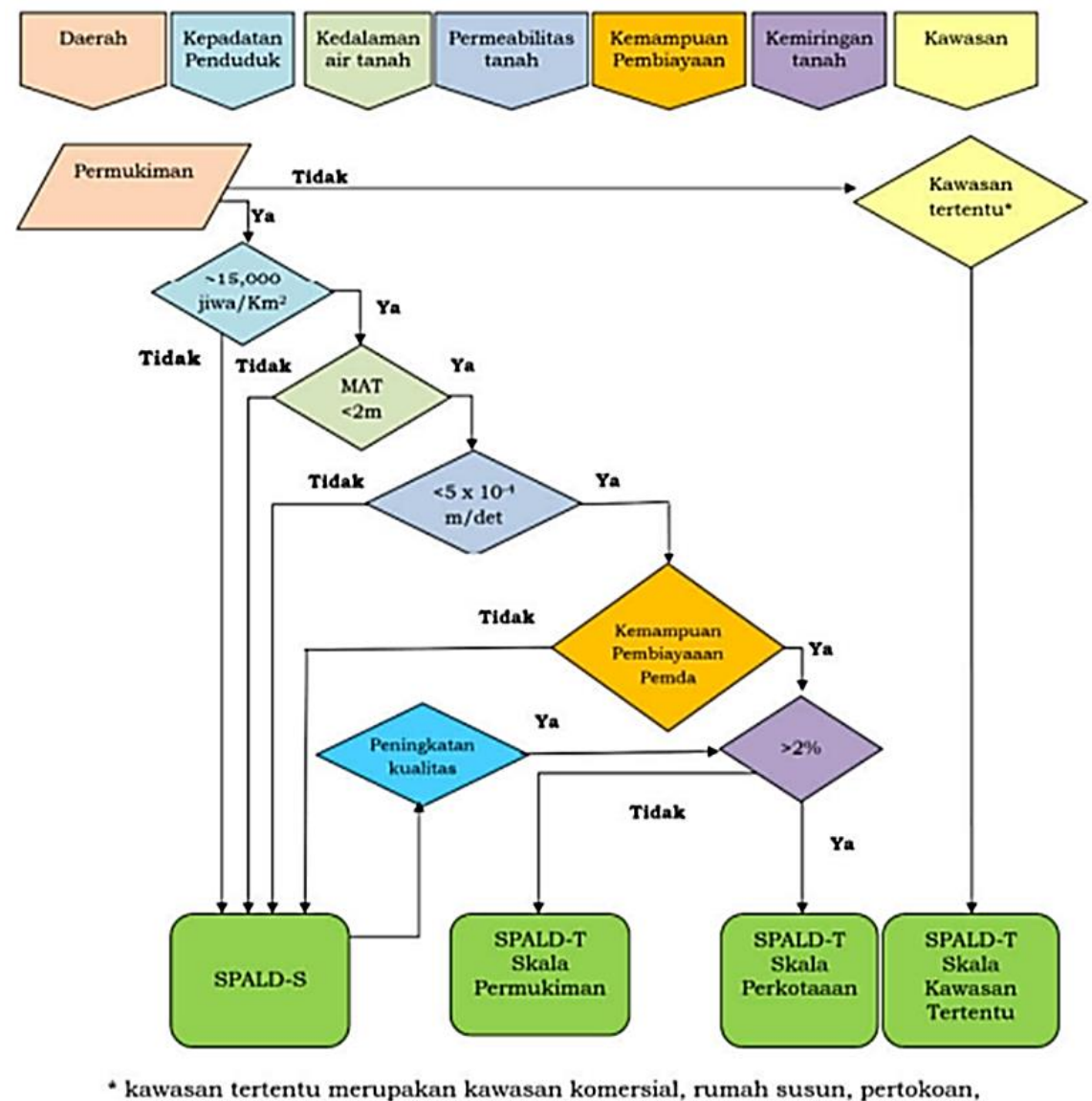

Gambar 1. Diagram Alir Pemilihan Jenis SPALD [4]

Dasar pertimbangan yang utama dalam pemilihan teknologi SPALD yaitu kepadatan penduduk. Kepadatan penduduk $>150 \mathrm{jiwa} / \mathrm{Ha}\left(15,000 \mathrm{jiwa} / \mathrm{Km}^{2}\right)$ dapat menerapkan sistem SPALD-T, sedangkan 
untuk kepadatan penduduk kurang dari 150 jiwa/Ha masih terdapat beberapa pertimbangan lainnya, seperti sumber air yang ada, kedalaman air tanah, permeabilitas tanah, kemiringan tanah, ketersediaan lahan, termasuk kemampuan membiayai. Contohnya apabila kepadatan penduduknya lebih dari 150 jiwa/Ha, kedalaman air tanahnya kurang dari $1 \mathrm{~m}$ dan tidak memiliki permeabilitas tinggi. Jika kemiringan tanahnya lebih dari $2 \%$ (dua persen) dan kemampuan membiayai memenuhi maka dapat menggunakan SPALD-T, sedangkan jika kemiringan tanahnya kurang dari 2\% (dua persen), maka terdapat pilihan teknologi lain tergantung pada kemampuan membiayai dan kecocokan teknologi yang dipilih [4].

\section{METODOLOGI}

Penelitian ini mengacu kepada Permen PUPR No 4/2017, dalam penelitian ini dimulai dengan melakukan pengumpulan data. Dua data yang dibutuhkan untuk penelitian ini yaitu data primer meliputi survei jalan, saluran drainase, sarana pembuangan tinja, dan sungai dan data sekunder meliputi data kependudukan, peta RTRW, peta Cekungan Air Tanah (CAT), peta Geologi, peta pengendalian pemanfaatan air tanah, dan peta potensi air tanah, Laporan studi Environmental Health Risk Assesment (EHRA), Rencana induk penyaluran air limbah domestik, Recana Pembangunan Jangka Menengah Daerah (RPJMD), dan Strategi Sanitasi Kota (SSK), dan regulasi penyaluran air limbah domestik. Datadata tersebut akan digunakan pada parameter-parameter dalam pemilihan jenis SPALD di Kecamatan Bekasi Selatan.

Penelitian ini dilakukan di Kecamatan Bekasi Selatan menggunakan cara penapisan. Penapisan merupakan proses seleksi meliputi parameter-parameter yang harus dipenuhi. Penapisan bertujuan untuk memilih jenis SPALD yang akan direncanakan. Penapisan pemilihan jenis SPALD ditetapkan dalam Lampiran I Permen PUPR No. 4/2017 tentang penyelenggaraan SPALD meliputi:

1. Kepadatan penduduk lebih dari 150 jiwa/Ha, jika tidak terpenuhi maka dilakukan SPALD-S, sedangkan jika terpenuhi dilakukan pengecekan pada parameter selanjutnya;

2. Kedalaman muka air tanah kurang dari 2 meter, jika tidak terpenuhi maka dilakukan SPALD-S, sedangkan jika terpenuhi dilakukan pengecekan pada parameter selanjutnya.;

3. Permeabilitas tanah kurang dari $5 \times 10^{-4} \mathrm{~m} /$ detik, jika tidak terpenuhi maka dilakukan SPALD-S, sedangkan jika terpenuhi dilakukan pengecekan pada parameter selanjutnya;

4. Kemampuan pembiayaan oleh pemerintah daerah, jika tidak terpenuhi maka dilakukan SPALD-S, sedangkan jika terpenuhi dilakukan pengecekan pada parameter selanjutnya;

5. Kemiringan tanah kurang dari 2\%, jika tidak terpenuhi maka dilakukan SPALD-T skala permukiman, sedangkan jika terpenuhi maka dilakukan SPALD-T skala perkotaan.

Tahapan penapisan di atas dilakukan menggunakan diagram alir berdasarkan Permen PUPR No 4/2017 yang disajikan pada Gambar 1. 


\section{HASIL DAN PEMBAHASAN}

Kecamatan Bekasi Selatan merupakan salah satu Kecamatan yang berada di Kota Bekasi. Secara geografi kecamatan ini berada pada posisi $106^{\circ} 58^{\prime} 25^{\prime}$ " bujur Timur dan 6 ${ }^{\circ} 16^{\prime} 1^{\prime \prime}$ lintang Selatan, dengan ketinggian $33 \mathrm{~m}$ di atas permukaan laut (dpl) dilihat dari stasiun Kota Bekasi [1].

\subsection{Kepadatan Penduduk}

Kepadatan penduduk adalah perbandingan jumlah penduduk dengan luas wilayah. Kepadatan penduduk yang disyaratkan untuk SPALD-T yaitu lebih dari 150 jiwa/Ha, jika tidak memenuhi maka digunakan SPALD-S. Data ini didapatkan dari buku Kecamatan Bekasi Selatan Dalam Angka Tahun 2017 pada Badan Pusat Statistik (BPS). Kecamatan Bekasi Selatan yang memiliki 5 kelurahan yaitu Kelurahan Jaka Mulya, Jaka Setya, Pekayon Jaya, Marga Jaya, dan Kayuringin Jaya. Kecamatan Bekasi Dalam Angka (2018) menginformasikan penduduk Kecamatan Bekasi Selatan pada tahun 2017 adalah 229.809 jiwa dengan luas wilayah $1.496 \mathrm{Ha}$, sehingga kepadatan penduduk Kecamatan Bekasi Selatan 154 Jiwa/Ha seperti yang dapat dilihat pada Tabel 1.

Tabel 1. Jumlah Penduduk. Luas Wilayah, dan Kepadatan Penduduk Kecamatan Bekasi Selatan [1]

\begin{tabular}{ccccc} 
No & Kelurahan & $\begin{array}{c}\text { Jumlah Penduduk } \\
(\text { Jiwa })\end{array}$ & $\begin{array}{c}\text { Luas Wilayah } \\
(\text { Ha })\end{array}$ & $\begin{array}{c}\text { Kepadatan Penduduk } \\
\text { (Jiwa/Ha) }\end{array}$ \\
\hline 1 & Jaka Mulya & 40.482 & 273 & 148 \\
\hline 2 & Jaka Setya & 41.840 & 331 & 13 \\
\hline 3 & Pekayon Jaya & 70.317 & 425 & 165 \\
\hline 4 & Marga Jaya & 16.193 & 209 & 77 \\
\hline 5 & Kayuringin Jaya & 60.977 & 258 & 236 \\
\hline & Jumlah & $\mathbf{2 2 9 . 8 0 9}$ & $\mathbf{1 . 4 9 6}$ & $\mathbf{1 5 4}$ \\
\hline
\end{tabular}

\subsection{Kedalaman Muka Air Tanah}

Berdasarkan Permen PUPR No. 4/2017, nilai MAT $<2 \mathrm{~m}$. Data ini diperoleh dari data kedalaman muka air tanah pada peta potensi air tanah dari Pusat Air Tanah dan Geologi Tata Lingkungan (PATGTL) Provinsi Jawa Barat. Kondisi kedalaman air tanah daerah perencanaan diperoleh berdasarkan peta potensi air tanah daerah Jonggol-Bekasi dan sekitarnya. Kecamatan Bekasi Selatan memiliki kedalalan sumur gali 4-16 m, dalam sumur bor $200 \mathrm{~m}$, dan kedudukan akuifer 0-50 m di bawah muka air tanah seperti yang dapat dilihat pada Gambar 2.

\subsection{Permeabilitas Tanah}

Berdasarkan Permen PUPR No. 4/2017, nilai permeabilitas tanah kurang dari $5 \times 10^{-4} \mathrm{~m} /$ detik. Data ini diperoleh dari jenis tanah daerah setempat melalui Peta Gologi dari Pusat Air Tanah dan Geologi Tata Lingkungan (PATGTL) Provinsi Jawa Barat. Jenis tanah kecamatan Bekasi Selatan sebagian besar aluvial serta tekstur tanah didominasi sedang halus berdasarkan peta Geologi lembar Jakarta dan Kepulauan Seribu seperti yang dapat dilihat pada Gambar 3. 


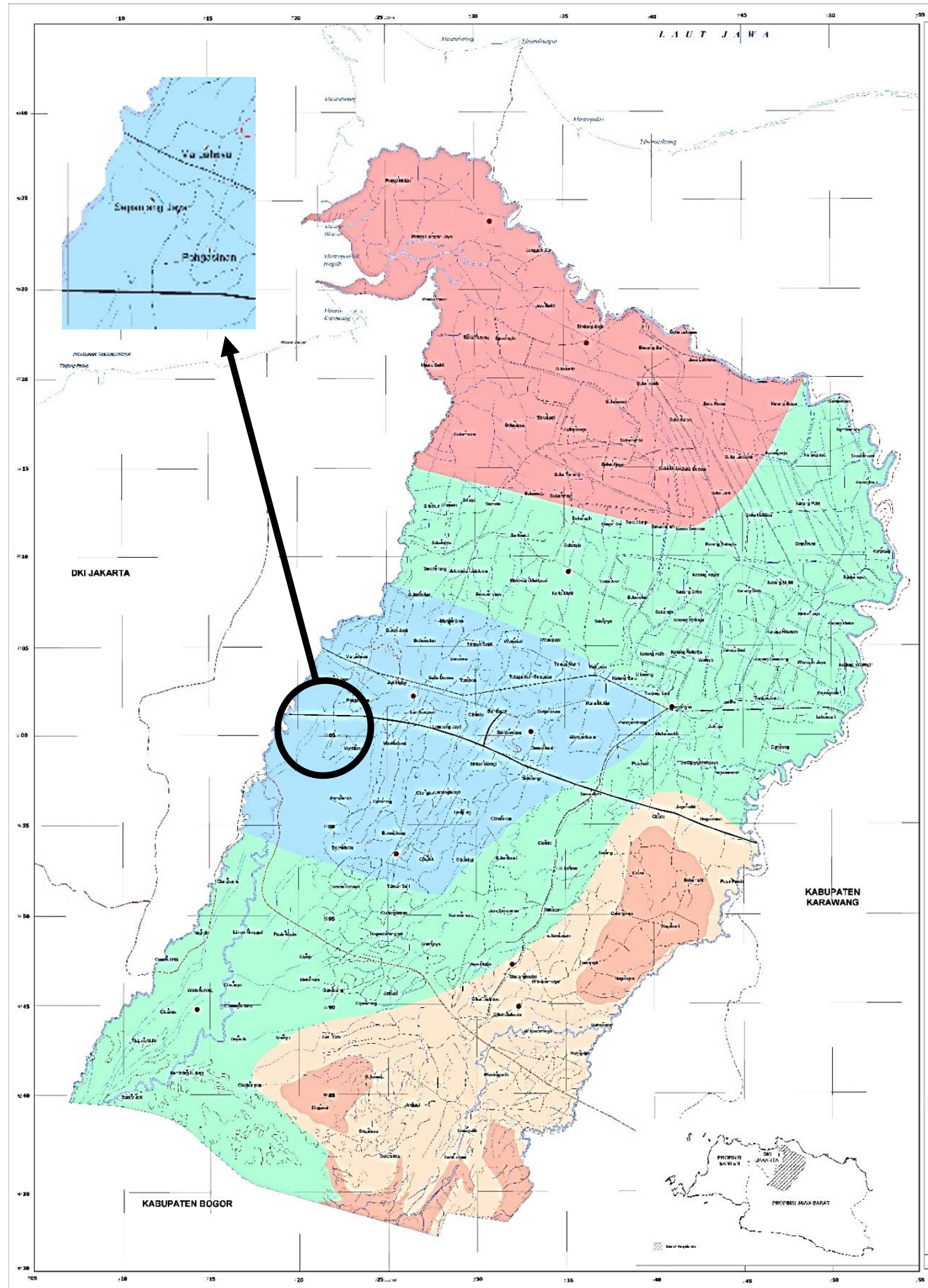

Gambar 2. Peta Potensi Air Tanah Daerah Jonggol-Bekasi dan Sekitarnya [6]

Ket:

: Dalam sumur gali 4-16 m; dalam sumur bor $200 \mathrm{~m}$; dan Kedudukan akuifer 0-50 m. 


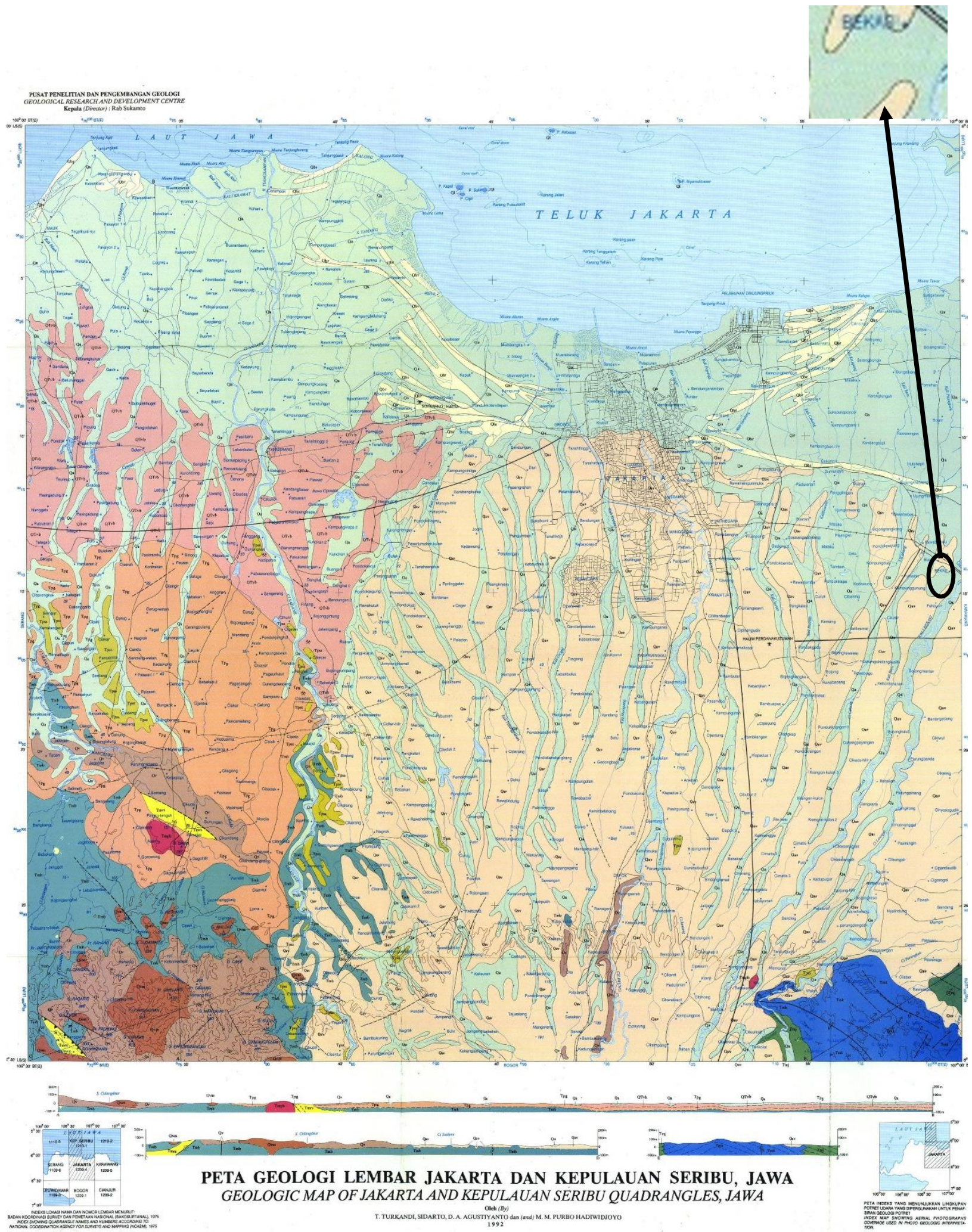

Gambar 3. Peta Geologi Lembar Jakarta dan Kepulauan Seribu [6]

Ket:

: Jenis tanah aluvial dengan komposisi lempung, lanau, pasir, kerikil,kerakal, dan bongkah. Jenis tanah aluvial dapat di padankan dengan padanan klasifikasi taksonomi tanah berdasarkan sistem 
yang digunakan di Indonesia meliputi klasifikasi tanah sistem nasional, FAO, dan soil taxonomy seperti yang dapat dilihat pada Tabel 2.

Tabel 2. Pendanaan Klasifikasi Taksonomi dan Penamaan Tanah [7]

\begin{tabular}{c|ccc|}
\hline $\begin{array}{c}\text { Sistem Dual/Soepraptohardjo } \\
\text { (1961) }\end{array}$ & $\begin{array}{c}\text { Sistem PPT, Bogor } \\
\text { Modifikasi (1983) }\end{array}$ & $\begin{array}{c}\text { Sistem FAO/UNESCO } \\
\text { Aluvial }\end{array}$ & $\begin{array}{c}\text { Sistem Taksonomi } \\
\text { Tamah (1975) }\end{array}$ \\
\hline & Aluvial & Cambiosol & Inceptisols \\
& Brunizem & Cambiosol & Inceptisols \\
& Nitosol & Cambiosol & Inceptisols \\
& - & Nitosol & Ultisol \\
& - & Phaeozem & Alfiosol \\
& Oksiosol & - & Mollisols \\
& & Ferralsol & Oxisols \\
\hline
\end{tabular}

Sistem nasional pada jenis aluvial, setara dengan cambiosol menurut FAO, dan Inceptisol menurut soil taxonomy. Berdasarkan penelitian menganalisis perbedaan pengukuran di lapangan dan di laboratorium Uhland dan O'neal dalam siregar [7] sistem taksonomi tanah digunakan untuk mengetahui nilai laju permeabilitas tanah di laboratorium maupun lapangan seperti yang dapat dilihat pada Tabel 3.

Tabel 3. Nilai Permeabilitas Hasil Pengukuran [7]

\begin{tabular}{|c|c|c|c|}
\hline \multirow[t]{2}{*}{ Jenis Tanah } & \multicolumn{2}{|c|}{ Laju Permeabilitas Tanah (cm/jam) } & \multirow[t]{2}{*}{ Keterangan } \\
\hline & Laboratorium & Lapangan & \\
\hline Andepts & 1,34 & 1,26 & Agak lambat \\
\hline Inceptisol & 3,20 & 2,23 & Sedang \\
\hline Ultisol & 1,06 & 0,98 & Agak lambat \\
\hline
\end{tabular}

Hasil padanan yang digunakan adalah sistem taksonomi tanah, sehingga didapatkan tanah Kecamatan Bekasi Selatan berjenis Inceptisol dengan kategori sedang. Nilai permeabilitas tanah inceptosols sebesar $3,2 \mathrm{~cm} / \mathrm{jam}$ untuk pengukuran di lapangan, dan $2,23 \mathrm{~cm} / \mathrm{jam}$ untuk pengukuran di laboratorium. Dilakukan konversi pada satuan untuk mendapatkan nilai permeabilitas yang diinginkan, sehingga didapatkan nilai permeabilitas pada pengukuran laboratorium $8,89 \times 10^{-6} \mathrm{~m} /$ detik dan pada pengukuran lapangan $6,19 \times 10^{-6} \mathrm{~m} /$ detik.

\subsection{Kemampuan Pembiayaan}

Berdasarkan Permen PUPR No. 4/2017, untuk pembangunan jenis jaringan perpipaan SPALD dapat ditentukan dari kemampuan pembiayaan dalam pengoperasian dan perawatan. Data ini didapatkan melalui kemampuan pendanaan sanitasi yang tertera di Anggaran Pendapatan dan Belanja Negara (APBN) yang telah di aloasikan ke Anggaran Pendapatan dan Belanja Daerah (APBD) dari Masterplan Penyaluran Air Limbah Domestik Kota Bekasi.

Berdasarkan Perhitungan Pertumbuhan Pendanaan APBD Kota Bekasi, dinyatakan bahwa terdapat dana belanja APBD murni untuk sanitasi sejak tahun 2010. Kemampuan pendanaan pendanaan APBD untuk belanja sanitasi kota Bekasi pada tahun 2014 berjumlah Rp.2.545.203.789.960,- 


\subsection{Kemiringan Tanah}

Berdasarkan Permen PUPR No. 4/2017 [4], nilai kemiringan tanah lebih dari 2\% sebagai syarat pembuatan SPALD-T skala perkotaan, jika kurang dari sama dengan 2\% maka pembuatan SPALD-T dilakukan untuk skala permukiman. Data ini tertera pada peta kemiringan tanah dari rencana induk penyaluran air limbah domestik Kota Bekasi. Kecamatan Bekasi Selatan memiliki kemiringan 1-2\% seperti yang dapat dilihat pada Gambar 4.

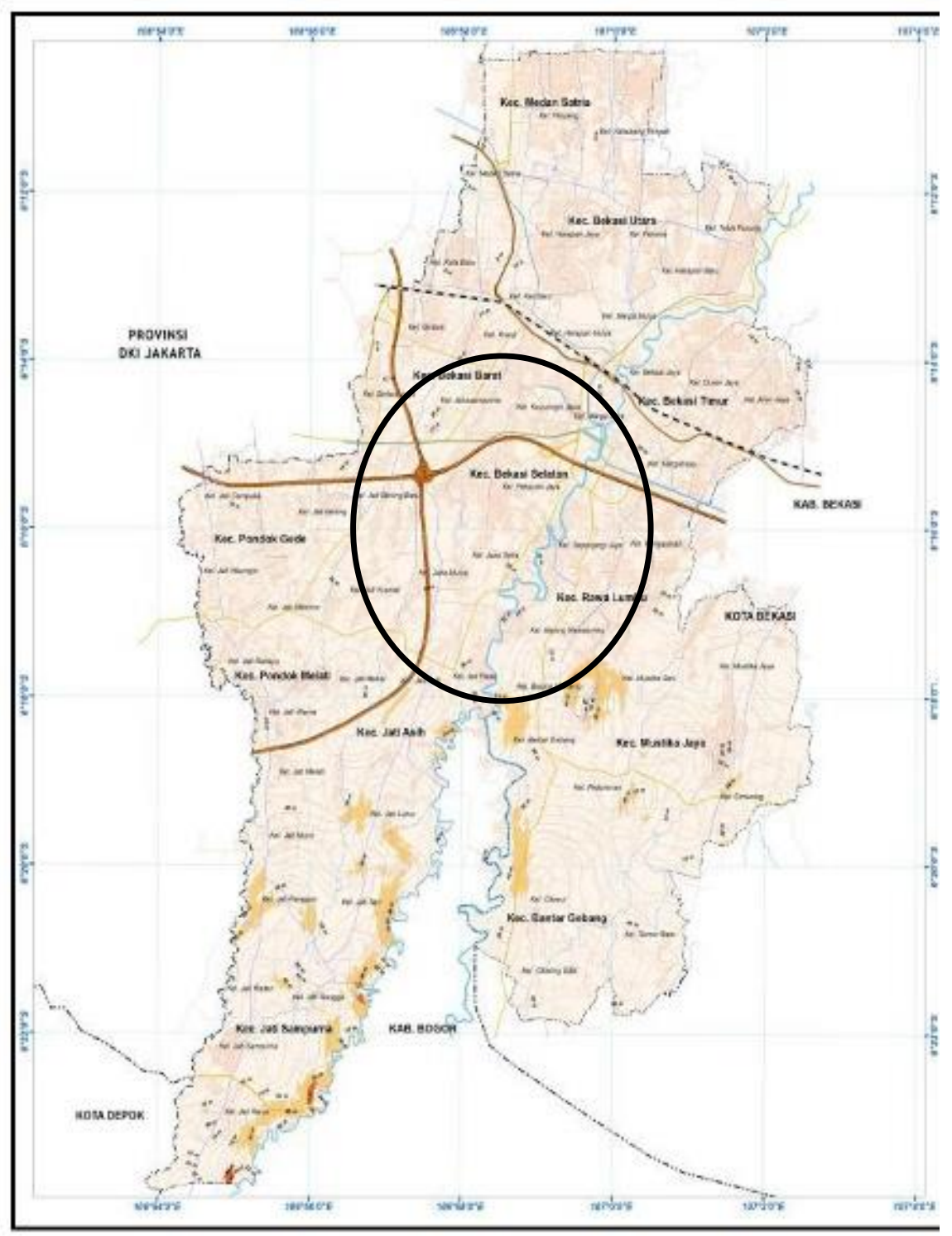

Gambar 4. Peta Kemiringan Tanah Kota Bekasi [5]

Sumber: Rencana Indusk SPAL Kota Bekasi, 2015

Ket:

: Kemiringan Lereng 1-2\%

Penentuan jenis SPALD Kecamatan Bekasi Selatan berdasarkan Permen PUPR No. 4/2017 pada parameter kepadatan penduduk, kedalaman muka air tanah, permeabilitas tanah, kemampuan pembiayaan, dan kemiringan tanah dapat dilihat pada Tabel 4. 
Tabel 4. Penentuan Jenis SPALD Kecamatan Bekasi Selatan

\begin{tabular}{|c|c|c|c|c|}
\hline Indikator & Kriteria & Eksisting & Keterangan & Sumber \\
\hline $\begin{array}{l}\text { Kepadatan } \\
\text { Penduduk }\end{array}$ & $150 \mathrm{jiwa} / \mathrm{ha}$ & 154 Jiwa/Ha & Memenuhi & $\begin{array}{l}\text { BPS, Kecamatan Bekasi } \\
\text { Selatan Dalam Angka } 2018\end{array}$ \\
\hline $\begin{array}{l}\text { Muka Air } \\
\text { Tanah }\end{array}$ & $<2 \mathrm{~m}$ & $\begin{array}{l}\text { - } \quad \text { kedalalan sumur gali } \\
\text { 4-16 m, } \\
\text { - } \quad \text { kedalaman sumur bor } \\
200 \mathrm{~m}, \text { dan } \\
\text { - } \quad \text { kedudukan akuifer 0- } \\
50 \mathrm{~m}\end{array}$ & $\begin{array}{c}\text { Tidak } \\
\text { Memenuhi }\end{array}$ & $\begin{array}{l}\text { Peta potensi air tanah } \\
\text { daerah Jonggol-Bekasi dan } \\
\text { sekitarnya, } 1997\end{array}$ \\
\hline $\begin{array}{l}\text { Permeabilitas } \\
\text { Tanah }\end{array}$ & $5 \times 10^{-4} \mathrm{~m} / \mathrm{det}$ & $\begin{array}{lll}\text { - } & 6,19 \times 10^{-6} \text { untuk } \\
& \text { pengukuran lapangan } \\
\text { - } & 8,89 \text { x } 10^{-6} \text { untuk } \\
& \text { pengukuran lab }\end{array}$ & Memenuhi & Siregar, 1993 \\
\hline $\begin{array}{l}\text { Kemampuan } \\
\text { Pembiayaan }\end{array}$ & Mampu & APBN dan APBD II & Memenuhi & RTRW Kota Bekasi, 2015 \\
\hline $\begin{array}{l}\text { Kemiringan } \\
\text { Tanah }\end{array}$ & $>2 \%$ & $1-2 \%$ & $\begin{array}{c}\text { Tidak } \\
\text { Memenuhi }\end{array}$ & $\begin{array}{l}\text { Masterplan Penyaluran Air } \\
\text { Limbah Kota Bekasi, } 2015\end{array}$ \\
\hline
\end{tabular}

Berdasarkan Tabel 4 dapat diketahui bahwa 3 parameter yang terdiri dari kepadatan penduduk, permeabilitas tanah, dan kemampuan pembiayaan Kecamatan Bekasi Selatan memenuhi syarat yang ditetapkan di untuk penentuan cakupan pelayanan SPALD-T skala perkotaan, sedangkan pada parameter kemiringan tanah tidak memenuhi. Sesuai dengan diagram alur pemilihan jenis SPALD.

\section{KESIMPULAN}

Kecamatan Bekasi Selatan pada tahun 2017 memiliki kepadatan penduduk 154 jiwa/Ha, muka air tanah 4-200 m dengan kedalalan sumur gali 4-16 m dan kedalaman sumur bor $200 \mathrm{~m}$,, permeabilitas tanah 6,19-8,89 x $10^{-6} \mathrm{~m} /$ detik, mampu dalam memenuhi terdapat dana belanja APBD murni untuk sanitasi sejak tahun 2010 sejumlah Rp.2.545.203.789.960,-, dan kemiringan tanah 1-2\%. Berdasarkan hasil tersebut, parameter kedalaman muka air tanah tidak memenuhi persyaratan Permen PUPR No.4/2017, sehingga jenis SPALD yang terpilih di Kecamatan Bekasi Selatan adalah SPALD-S skala komunal.

\section{DAFTAR PUSTAKA}

[1] BPS Kecamatan Bekasi Selatan. (2018). Kecamatan Bekasi Selatan Dalam Angka Tahun 2018. BPS. Bekasi.

[2] Environmental Health Risk Assesment (EHRA). (2015). Laporan Studi EHRA Kota Bekasi Tahun 2015. BAPPEDA Kota Bekasi. Bekasi.

[3] Fajarwati, A. (2000). Perencanaan Sistem Penyaluran Air Buangan Domestik Kota Palembang (Studi Kasus: Kecamatan Ilir Timur I dan Kecamatan Ilir Timur II)(Skripsi). Program Sarjana, Institut Teknologi Bandung. Bandung.

[4] Peraturan Menteri Pekerjaan Umum dan Perumahan Rakyat No. 04 Tahun 2017 tentang Penyelenggaraan Sistem Pengelolaan Air Limbah Domestik

[5] Masterplan Air Limbah Kota Bekasi. 2015. Masterplan Air Limbah Kota Bekasi. BAPPEDA Kota Bekasi. Bekasi Dinas Lingkungan Hidup (DLH) Provinsi Jawa Barat.

[6] Kementrian ESDM, (2019) Peta Potensi Air Tanah, Pusat Air Tanah dan Geologi Tata Lingkungan 
Provinsi Jawa Barat. Bandung

[7] Siregar. (2013). Kajian Permeabilitas Beberapa Jenis Tanah Di Lahan Percobaan Kwala Bekala Usu Melalui Uji Laboratorium Dan Lapangan. USU. Medan. 